\title{
Tax Objection Agency in Indonesia
}

\author{
Alessandro Rey \\ \{info@reyandco.co.id $\}$ \\ Rey \& Co Jakarta Attorneys at Law, Wisma Bayuadji Floor 2, Suite \# 205, Jalan Gandaria Tengah III \\ No. 44, Kebayoran Baru, Jakarta Selatan 121301
}

\begin{abstract}
Tax assessment letter (SKP) issued by Director General of Taxes of Republic of Indonesia (Fiskus) often causes quite crucial problems between taxpayers and fiskus. This is due to tax law interpretation between taxpayers and fiskus in determining the amount of tax to be paid. Therefore, if they feel less or not satisfied with SKP, taxpayer could file an objection. Objection is a legal action outside tax court, whose procedure for resolving is often not in accordance with the prevailing laws and uses a legal basis that is contrary to the principle of legality and non-retroactivity. The quality of the objection process should not only focus on timeline, but also on procedures that comply with the applicable laws. The authority of fiskus as one of the state executive bodies to resolve tax disputes in the form of objection is claimed ineffective and unable to provide justice.
\end{abstract}

Keywords: Procedures of Objection; Tax Invoice; Administrative Sanction

\section{Introduction}

The taxation system in Indonesia adheres to the principle of self-assessment system in which taxpayers are given the authority to calculate, pay and report their tax obligation. One example is the tax obligation in the form of Value Added Tax (VAT). In this case, part of VAT is the issuance of tax invoice. Issuance of tax invoice in the right form is an important part of VAT collection and crediting procedure. Each form of invoice specified in Law Number 8 Year 1983 concerning Value Added Tax on Goods and Services and Sales Tax on Luxury Goods as amended several times, most recently by Law Number 42 Year 2009 (UUPPN) [1] can be used as evidence for Taxpayers who have implemented self-assessment system principles properly. Basically, efficient tax administration will be achieved well if fiskus in carrying out their duties and authorities comply with the provisions of the prevailing laws.

Indonesia is a constitutional state based on Article 1 point 3 of 1945 Constitution of Republic of Indonesia (UUD 1945) [2], so every action and laws made by the government must be based on 1945 Constitution. In enforcing laws must be based on constitution. According to (Atmadja, 2018), One of the Legal principles that is still valid and very well-known is principle of legality and non-retroactivity [3]. The state gives authorities to Fiskus to carry out the functions of counseling, services, supervision and law enforcement efforts to taxpayers. One form of fiskus supervision is in the form of audit which will determine the amount of tax to be paid by taxpayer and the legal output issued by Fiskus is SKP. The calculation in SKP by the fiskus is often not in accordance with the calculation according to the taxpayer, causing tax disputes.

In the event of a tax dispute, taxpayer is entitled to legal protection which aims to provide a sense of justice for taxpayer in resolving tax disputes. Settlement of tax disputes between taxpayers and fiskus can be executed through administrative efforts by filing an objection. The 
objection process is a legal action outside the tax court. The mandate for resolving objection filing is stated in Article 25 paragraph (1) of Law of Republic of Indonesia Number 16 of 2009 concerning Stipulation of Government Regulations in Lieu of Law Number 5 of 2008 concerning the Fourth Amendment to Law Number 6 of 1983 Concerning General Provisions and Procedures to become Law (UUKUP) [4].

During the process, two parties are summoned in turn to be asked for information and prepare evidence in the form of data and information in accordance with the object of the dispute so that fiskus represented by Objection Review Team (PK Team) could make decision appropriately and accurately, therefore the principle of justice can be felt by taxpayer. In resolving tax disputes, fiskus must follow standard procedures as stipulated by Director General of Taxes Circular Number SE-11/PJ/2014 concerning Implementation Guidelines for Settlement of Objection for Income Tax, Value Added Tax and/or Sales Tax on Luxury Goods (SE 11/2014) [5].

In this study, the author analysed tax dispute of PT Mitra Abadi Pratama (PT MAP) in 2016 tax audit and the author also analysed the procedures of tax objection as stipulated in SE $11 / 2014$.

\section{Discussion}

The research method used by the author is a normative juridical research method. In normative research, answers to existing problems are obtained from various literatures. From this description, it can be concluded that the normative legal research method is a scientific research procedure to find the truth based on the scientific logic of laws from and based on applicable legal norms. Research in this journal uses normative legal research because this research is carried out through literature research which includes research on legal principles and legal systems to obtain secondary data which includes primary legal materials, secondary legal materials, tertiary legal materials and non-legal materials. This journal writing attempts to examine tax law or norm related to objection legal action.

The approach method used in this research is the Case Study Research method which is based on normative juridical studies because the focus of this research is laws or norms related to objection legal action. The method here includes legal principles and legal norms which are concrete legal rules and related legal systems.

\section{Application of VAT Law in a Tax Dispute Perspective}

PT MAP is a company that distributes PT Philips Indonesia Commercial (PT PIC) products, where every transaction there must be an agreement between the two parties. In the event of a transaction such as buying and selling, there must be evidence and one of them is tax invoice. According to Waluyo (2009: 270) Definition of Tax Invoice is evidence of collection made by a Taxable Entrepreneur (PKP) due to the delivery of Taxable Goods (BKP) or delivery of Taxable Services (JKP) or proof of tax collection because of import of Taxable Goods by Director of Customs and Excise (DJBC). [6]

Along with the development of technology and information, VAT reporting continues to experience developments ranging from manual reports (using hard copies) to changes in electronic form. This aims to minimize fraud that often occurs in reporting payable taxes and simplify the procedures for reporting Tax Returns (SPT). 
Therefore, fiskus launched a new program, namely E-Invoice or electronic tax invoice. What is meant by E-Invoice is a Tax Invoice made through an application or electronic system that is provided by Director General of Taxes (Sakti and Hidayat, 2015: 123) [7]. The enactment of E-Invoice is intended to provide convenience, comfort, and security for Taxable Entrepreneurs in carrying out VAT tax obligations, especially in terms of making tax invoices. (Sarah, Sandra, 2016: 113) [8]. PT MAP has purchased two items from PT PIC with different tax invoice numbers, namely 010.000-16.76522928 (tax invoice 1) and 010.000-16.76522929 (tax invoice 2) and PT MAP has paid VAT tax of 10\% (ten percent) on February 18, 2016.

In accordance with the provisions of UUPPN that tax invoice can be credited, therefore PT MAP credits their own tax invoice. And according to taxation system in Indonesia, PT MAP has calculated, paid and reported VAT in the tax return for the tax period February and tax year 2016. Then PT PIC as the counterparty of PT MAP's transaction has issued a replacement tax invoice in order to correct the previous Tax Invoice, namely number 010.000-16.76522928 (tax invoice 1) changed to 011.000-16.76522928 (tax invoice 3) and tax invoice number 010.00016.76522929 (tax invoice 2) changed to tax invoice number 011.000-16.76522928 (tax invoice 4).

However, PT MAP was not notified of the issuance of replacement tax invoices by PT PIC. In the replacement tax invoices, there are only a difference in the description of the types of goods being purchased, while the nominal transaction and VAT remain the same. No price difference was found. Then when the audit was carried out, fiskus found that there was a difference in tax invoice number which was already credited by PT MAP. Fiskus considered that the difference in tax invoice number did not meet the formal requirements therefore it should not have been credited. This is in accordance with the provision in article 9 paragraph (8) letter f UUPPN which states that tax crediting cannot be applied to expenditures for the acquisition of Taxable Goods whose Tax Invoice does not meet the provision as referred to in Article 13 paragraph (5) or paragraph (9) UUPPN because it does not include the name, address and Taxpayer Identification Number of buyers of Taxable Goods or recipient of Taxable Service.

In article 13 paragraph (5) UUPPN regulates formal provision related to information that must be included in tax invoice. Article 13 paragraph (5) UUPPN only states that a tax invoice cannot be credited if it does not meet the formal requirements. Therefore, this provision when interpreted in a contrario argumentum does not prevent the crediting of tax invoice that only meets material requirements. In accordance with the provision in elucidation of article 29 paragraph (2) UUKUP which states that fiskus in providing opinions and conclusions must be based on strong evidence and based on the provisions of laws.

Having the proof of purchase transaction of goods and payment of VAT on the tax invoice that has been credited by PT MAP, has fulfilled the material requirements perfectly. Therefore, it does not violate the provision in Article 9 paragraph (8) letter f UUPPN. The Abovementioned is strengthened by elucidation in Article 76 of Law Number 14 of 2002 concerning the Tax Court (UUPP) [9] which states that the tax court in determining the burden of proof of tax disputes is to seek material truth. Therefore, tax invoices that only meet material requirements can be credited because they do not violate with applicable laws.

The legality principle of Director General of Taxes Regulation Number PER-32/PJ/2017

The difference in tax invoice number that had been credited by PT MAP has caused fiskus to impose administrative sanction in the form of $100 \%$ (one hundred percent) increase from the value of VAT based on Article 13 paragraph 3 UUKUP. The sanction imposed by fiskus on PT MAP is claimed unlawful because PT MAP has made VAT payments on the sale and purchase 
transaction and based on the provision in Article 4 paragraph (2) Government Regulation Number 1 of 2012 concerning Implementation of Services and Sales Tax on Luxury Goods as amended several times, most recently by Law Number 42 of 2009 concerning the third amendment to Law Number 8 of 1983 concerning Value Added Tax on Goods and Services and Sales Tax on Luxury Goods (PP1/2012) [10] which states that buyer of taxable goods or recipient of service is not jointly responsible for VAT payments if they can show evidence of having made VAT payments to goods seller or service provider.

An administrative sanction was imposed due to the existence of DGT Announcement Number PENG-07/PJ.09/2017 Regarding Down-Time Notification of E-Nofa and E-Invoice Applications and Launching of Desktop E-Invoice Application Version V2.0, Web-Based EInvoice, And Host-To-Host E-Invoice (PENG 07/2017) [11] which then enacted DGT Regulation Number Per-32/PJ/2017 concerning Amendments to Regulation of Director General of Taxes Number Per-41/PJ/2015 concerning Security of Electronic Transactions of Online Tax Services (PER 32/2017) [12].

The announcement and fiskus regulation mean that every tax invoice issuance between seller and buyer or between provider and recipient must match the invoice number and be issued simultaneously. This was not carried out by PT MAP because there was no notification from PT PIC as the transaction counterparty. At the time of tax audit, PT MAP was subject to administrative sanction imposed by fiskus. The sanction imposed by fiskus for PT MAP is far from being just because PT MAP's tax invoices had been credited in 2016, while the launch of the E-Invoice Application was announced and promulgated in 2017, therefore if this provision is applied to PT MAP's tax invoices, it violates the legal principle of legality and a retroactive principle, because the incident already took place and there was no law available yet at that time.

According to Joshua Dressler, the application of the retroactive principle is unfair because only new laws can be applied prospectively, therefore retroactive application of new laws can damage law enforcement system. [13]. The principle of justice in the 5th Indonesian ideology which states social justice for all Indonesian people implies that tax collection must reflect justice both in its laws and in its application.

\section{Objection Procedures Which Fiskus Often Ignores}

Regarding the administrative sanction, PT MAP filed a legal action in the form of an objection. The procedure for resolving objection is Regulated by Minister of Finance of Republic of Indonesia Number 202/PMK.03/2015 concerning Amendments to Regulation of Minister of Finance Number 9/PMK.03/2013 concerning Procedures for Filing and Resolving Objection (PMK 202/2015 Jo. PMK 9/2013) [14].

PMK regulates that before Director General of Taxes issues notification letter for taxpayer to attend objection hearing, Director General of Taxes requests additional information and data from Taxpayer. Provision regarding legal action for objection is also regulated by Director General of Taxes Regulation Number PER-49/PJ./2009 concerning Procedures for Filing and Resolving Objection (PER 49/2019). [15] The procedures for objection include the following:

a. Filing objection;

b. Fiskus through PK Team issues a notification letter to attend objection hearing;

c. Fiskus makes Minute of tax discussion and clarification;

d. Fiskus re-issues a notification letter to attend temporary hearing result (SPUH) along with 2 (two) attachments, namely a list of hearing results and a response form for a list of hearing results;

e. Taxpayer fulfils the notification letter to come to PK Team and provides a written response to the list of hearing results made by PK Team. 
f. Parties make Minute of attendance and submit written response to the list of hearing results;

g. PK Team issues objection decision within 12 (twelve months) since receipt of objection filing by PK Team. (Article 17 paragraph (1) PMK 9/2013 Jo. PMK 202/2015)

Further provision relating to objection procedures is governed by SE 11/2014. In SE $11 / 2014$, it regulates the existence of an assignment letter which becomes the legal basis for PK Team to review tax objection. The definition of assignment (ST) is an official letter made by an authorized superior official to another lower official who is assigned what must be done. What happened in PT MAP case was that when asked the assignment letter, fiskus could not show the assignment letter properly. The assignment letter(s) that should be shown are both valid assignment and replaced assignment letters.

A government administrative procedure can be considered good if it follows the legal basis governing the procedure itself. At the final stage in the objection process, taxpayer is invited by PK Team to present rebuttal regarding the objection hearing results. The discussion was carried out by both parties, namely fiskus and PT MAP based on SPUH. In fact, some of PK Team members were not present at the time of hearing and rebuttal, but they participated in the signing of the minutes. This is certainly very inappropriate from a legal point of view and can be said to be an act against the law. As one of the state executive bodies, Fiskus oversees implementing laws, including UUKUP. The quality of the objection process should not only focus on timeline, but also procedures that are in accordance with applicable laws in order to provide fair and efficient results for parties who have tax disputes.

Due to the non-fulfillment of the objection procedures by PK Team, violates procedures stipulated in SE 11/2014, therefore PT MAP as Taxpayer filed a lawsuit against Fiskus at Tax Court.

\section{Conclusion}

In accordance with the discussion that has been described by the author above, the author draws the following conclusions:

a. UUPPN is a tax law that is material in nature which regulates the subject, object, and tax rate for value added tax and tax on the sale of luxury goods. UUPPN as a Tax Law which in its application needs to be interpreted broadly and deeply based on the interpretation of the applicable laws so that there are no errors in the interpretation of the meaning because many parties often err in applying the legal enterpretation to a case, especially tax case.

b. Fiskus considers that PT MAP has caused losses to the state for crediting tax invoice and does not report the correction of VAT SPT for the periode February and for the tax year 2016. Thus, PT MAP was subject to VAT reimbursement and administrative sanction in the form of $100 \%$ (one hundred percent) increase. The stipulation of administrative sanction imposed by fiskus in the form of an increase based on article 13 paragraph 3 UUKUP violates the principles of legality and non-retroactivity due to the announcement regarding the launch of the E-Invoice application and online tax services as regulated in the Per$32 / \mathrm{PJ} / 2017$ came into effect in 2017, therefore if it is applied to 2016 PT MAP tax invoice it can be said that the application is retroactive, thus making the law very inefficient and shows that fiskus as one of the state executive bodies is claimed incapable of providing justice.

c. The objection procedures are very ineffective and violate the existing provision as stipulated in SE 11/2014. In this case, the objection procedure is executed without 
assignment letter as the legal basis by fiskus to make objection decision and also the absence of several members of PK Team but participating in signing minutes of hearing and rebuttal.

Furthermore, based on these conclusions, the author provides suggestions as follows:

a. There is a need of socialization for fiskus through PK Team if there is a change of laws so that there is no retroactive application of the laws which results in losses of taxpayers and so that fiskus would not act arbitrarily in issuing SKP.

b. It is necessary to revise SE 11/2014 by stating an obligation for PK Team to show assignment letter before the objection process begins and if it is not fulfilled it can result in the cancellation of the Objection Decision.

\section{References}

[1] Law Number 8 Year 1983 concerning Value Added Tax on Goods and Services and Sales Tax on Luxury Goods as amended several times, most recently by Law Number 42 Year 2009 (UUPPN)

[2] 1945 Constitution of Republic of Indonesia (UUD 1945)

[3] Dewa Gede Atmadja.: Jurnal Kertha Wicaksana. Vol 12. Asas-Asas Hukum Dalam Sistem Hukum. (2018)

[4] Law of Republic of Indonesia Number 16 of 2009 concerning Stipulation of Government Regulations in Lieu of Law Number 5 of 2008 concerning the Fourth Amendment to Law Number 6 of 1983 Concerning General Provisions and Tax Procedures to Become Law (UUKUP)

[5] Circular of Director General of Taxes Number SE-11/PJ/2014 concerning Implementation Guidelines for Settlement of Objection for Income Tax, Value Added Tax and/or Sales Tax on Luxury Goods (SE 11/2014)

[6] Waluyo.: Akuntansi Pajak. Jakarta. Salemba Empat (2009)

[7] Nufransa Wira Sakti dan Asrul Hidayat.: "E-Faktur" Mudah dan Cepat Penggunaan Faktur Pajak Online. Jakarta. Visimedia Pustaka. (2015)

[8] Vivi Anita Sarah, Amelia Sandra.: Analisis Pemberlakuan E-Faktur PPN. Program Studi Akuntansi. Vol. 5 Jurnal Akuntansi Perpajakan. (2016)

[9] Law Number 14 of 2002 Concerning the Tax Court (UUPP)

[10] Government Regulation Number 1 of 2012 concerning Implementation of Services and Sales Tax on Luxury Goods as amended several times, most recently by Law Number 42 of 2009 concerning the third Amendment to Law Number 8 of 1983 concerning Value Added Tax on Goods and Services and Sales Tax on Luxury Goods (PP1/2012)

[11] DGT Announcement Number PENG-07/PJ.09/2017 Regarding Down-Time Notification of E-Nofa and E-Invoice Applications and Launching of Desktop E-Invoice Application Version V2.0, WebBased E-Invoice, And Host-To-Host E-Invoice (PENG 07/2017)

[12] DGT Regulation Number Per-32/PJ/2017 concerning Amendments to Regulation of Director General of Taxes Number Per-41/PJ/2015 concerning Security of Electronic Transactions of Online Tax Services (PER 32/2017)

[13] Joshua Dessler.: Understanding Criminal Procedure, 2nd edition. USA. Matthew Bender \& Company Incorporated.pp.50 (1996)

[14] Regulation of Minister of Finance of Republic of Indonesia Number 202/PMK.03/2015 concerning Amendments to Regulation of Minister of Finance Number 9/PMK.03/2013 concerning Procedures for Filing and Resolving Objection (PMK 202/2015 Jo. PMK 9/2013)

[15] Regulation of Director General of Taxes Number PER- 49/PJ./2009 concerning Procedures for Filing and Resolving Objection (PER 49/2019) 